\title{
Processing of Porous Silicon Oxycarbide Ceramics from Extruded Blends of Polysiloxane and Polymer Microbead
}

\author{
Young-Wook $\mathrm{KIM}^{\dagger}$, Chunmin WANG* and Chul B. PARK* \\ Department of Materials Science and Engineering, the University of Seoul, Seoul 130-743, Korea \\ *Microcellular Plastics Manufacturing Laboratory, Department of Mechanical and Industrial Engineering, \\ University of Toronto, ON, Canada M5S $3 G 8$
}

\begin{abstract}
Porous silicon oxycarbide (SiOC) ceramics with porosities ranging from $27 \%$ to $88 \%$ and a cell density higher than $10^{7}$ cells $/ \mathrm{cm}^{3}$ were made from polysiloxane and polymer microbead blends. The polysiloxane and polymer microbeads were compounded directly using a counter-rotated twin-screw extruder with a filamentary die. The obtained specimens were then transformed into porous SiOC ceramics using two different processes: (1) pyrolysis of the extruded blends and (2) foaming of the blends with gaseous carbon dioxide and subsequent pyrolysis. The pyrolysis process resulted in the production of closed-cell SiOC ceramics, while the combined foaming-pyrolysis process resulted in open-cell SiOC ceramics.
\end{abstract}

[Received March 14, 2007; Accepted June 14, 2007]

Key-words : Porous material, Porosity, Extrusion, Foaming, Polymer-derived ceramics

1. Introduction

Porous ceramics are of technological interest because of their unique characteristics such as low density, low thermal conductivity, high permeability, high surface area, high thermal shock resistance, and high specific strength. They also have the potential to be used in a wide range of applications including filtration, catalysis, thermal insulation, biomedical implants, preforms for metal-ceramic composites, impactabsorbing structures, absorbents, and gas sensors. ${ }^{1-5)}$ Since the distribution of the size and shape of the pore space in porous ceramics relates directly to their ability to perform a desired function in a particular application, the need to establish cell size and shape uniformity in order to achieve superior part properties, has been strongly emphasized. ${ }^{6), 7)}$

Porous ceramics can be fabricated by a variety of methods including replication methods, ${ }^{2), 8}$ direct foaming methods, ${ }^{3,99,10)}$ and sacrificial template methods. ${ }^{6,11)}$ Recently, two kinds of novel processing routes using polysiloxanes for fabricating microcellular silicon oxycarbide (SiOC) ceramics have been developed. The first strategy for manufacturing microcellular SiOC ceramics involves saturating preceramic polymers using gaseous, liquid, or supercritical $\mathrm{CO}_{2}$; nucleating and growing a large number of bubbles by inciting thermodynamic instability via a rapid pressure drop or heating; and transforming the microcellular preceramics into microcellular ceramics by pyrolysis and optional subsequent sintering. ${ }^{12), 13)}$ The second strategy entails forming shapes using a mixture of polysiloxane and expandable microspheres; foaming and cross-linking the compact by heating; and transforming the foamed polysiloxane-microsphere mixture into microcellular SiOC ceramics by pyrolysis. ${ }^{14), 15)}$ By controlling the processing parameters and composition, it is possible to adjust the porosity so that it ranges between $30 \%$ and $90 \%$. The advantages of using preceramic polymers for making porous ceramics are twofold; they favour a low processing temperature and enable the utilization of polymer processing. Ultimately, the variable rheological properties of preceramic polymers allow for a great deal of control over the processing.

Recently, our feasibility study demonstrated that a uniformly distributed, porous structure could be developed from various blends of polyolefin and preceramic polymers by first

\footnotetext{
† Corresponding author: E-mail address: ywkim@uos.ac.kr
}

fully compounding the blends and then subjecting them to controlled pyrolysis. ${ }^{16)}$ The following comprise the basic steps for producing porous ceramics: (i) compounding the preceramic polymers and the polyolefin; (ii) molding the shape of the articles; and (iii) transforming the obtained articles into porous SiOC ceramics by pyrolysis and subsequent sintering (the latter is optional).

The present study describes two kinds of simplified processes for preparing closed- and open-cell SiOC ceramics using a polysiloxane and polymer microbeads. The polysiloxane and polymer microbeads were compounded directly using a counter-rotated twin-screw extruder with a filamentary die. The extruded blends were then transformed into porous SiOC in two ways: (1) pyrolysis of the extruded blends and (2) foaming of the blends with gaseous carbon dioxide and subsequent pyrolysis. The pyrolysis process resulted in the creation of closed-cell SiOC ceramics, while the combined foaming-pyrolysis process produced open-cell SiOC ceramics. The microstructure, porosity, and cell density of porous SiOC ceramics are herein described.

\section{Experimental procedure}

The raw materials used in this experiment were commercially available polysiloxane (YR3370, GE Toshiba Silicones Co., Ltd., Tokyo, Japan) and polymer microbeads $(\sim 20 \mu \mathrm{m}$ and $\sim 50 \mu \mathrm{m}, 1.19 \mathrm{~g} / \mathrm{cm}^{3}$, poly (methyl methacrylate-co-ethylene glycol dimethacrylate), Sigma-Aldrich Inc., St. Louis, MO, USA). The pyrolysis of polysiloxane in an inert atmosphere yields $\mathrm{SiO}_{x} \mathrm{C}_{y}$, with a weight loss of about $13 \% .{ }^{17)}$ Three batches of raw materials were mixed, and the size and content of the microbeads were varied in order to characterize the effects of the above variables on the cell morphology and porosity (Table 1).

All individual batches were compounded directly using a counter-rotating twin-screw extruder with a filament die of $2.286 \mathrm{~mm}$ in diameter and $11.938 \mathrm{~mm}$ in length. The temperatures for the two heating sections of the barrel were set at $90^{\circ} \mathrm{C}$ and $115^{\circ} \mathrm{C}$, respectively. The die temperature was $130^{\circ} \mathrm{C}$ and the extruder speed was $40 \mathrm{rpm}$. For the pyrolysis process, the extruded specimens were cross-linked by doping a condensation catalyst (aminoalkylalkoxysilane) and subsequently heating the specimens up to $200^{\circ} \mathrm{C}$; they were then maintained at that temperature for $2 \mathrm{~h}$ in the air. The polysiloxane and poly- 
mer microbead blends were then pyrolyzed at $1200^{\circ} \mathrm{C}$ for $1 \mathrm{~h}$ in argon at a heating rate of $2^{\circ} \mathrm{C} / \mathrm{min}$. The heat treatment allows for the polymer-to-ceramic conversion of the preceramic foams, resulting in porous SiOC ceramics.

For the combined foaming-pyrolysis process, the extruded specimens were saturated with gaseous $\mathrm{CO}_{2}$ at room temperature for $24 \mathrm{~h}$ under a pressure of $5.5 \mathrm{MPa}$. Thermodynamic instability was then introduced by rapidly dropping the pressure to a rate of $3.9 \mathrm{MPa} / \mathrm{s}$. The foamed specimens were subsequently cross-linked by the same process used in the pyrolysis process. Finally, the foamed and cross-linked blends of polysiloxane and polymer microbead were pyrolyzed at

Table 1. Sample Designation and Batch Compositions of the Porous Silicon Oxycarbide Ceramics

\begin{tabular}{|c|c|c|c|}
\hline \multirow{2}{*}{ Sample } & \multicolumn{3}{|c|}{ Batch composition (mass\%) } \\
\cline { 2 - 4 } & Polysiloxane* & Microbead A** & Microbead B*** \\
\hline SiOC1 & 60 & 40 & 20 \\
\hline SiOC2 & 80 & & 40 \\
\hline SiOC3 & 60 & & \\
\hline
\end{tabular}

** $\sim 20 \mu \mathrm{m}, 1.19 \mathrm{~g} / \mathrm{cm}^{3}$, Poly(methyl methacrylate-co-ethylene glycol dimethacrylate), Sigma-Aldrich Inc., St. Louis, MO, USA. *** $\sim 50 \mu \mathrm{m}, 1.19 \mathrm{~g} / \mathrm{cm}^{3}$, Poly(methyl methacrylate-co-ethylene glycol dimethacrylate), Sigma-Aldrich Inc., St. Louis, MO, USA. $1200^{\circ} \mathrm{C}$ for $1 \mathrm{~h}$ in argon at a heating rate of $2^{\circ} \mathrm{C} / \mathrm{min}$.

The microstructures of the pyrolyzed specimens were observed by scanning electron microscopy. The porosity of the obtained porous ceramics was measured on a polished surface using an image analyzer (Image-Pro Plus, Media Cybernetics, USA). The cell density of the porous ceramics was measured by counting the number of cells in a two-dimensional image on the microstructure and then converting it into a three-dimensional image. ${ }^{12)}$

\section{Results and discussion}

A uniformly mixed polysiloxane-polymer microbead blend was achieved using a counter-rotating twin-screw extruder. When the blend was pyrolyzed, the polymer microbeads were burned out and only SiOC ceramic remained.

Figure 1 shows typical fracture surfaces for the porous SiOC ceramics prepared using the pyrolysis process. A homogeneous cellular structure was obtained when pyrolysis was carried out at $1200^{\circ} \mathrm{C}$. As illustrated in Fig. 1, closed cells were formed for all specimens. The morphology of the cells that were replicated from the polymer microbeads was almost spherical, indicating that the microbead shape was retained in the blend up until the polymer microbeads reached their decomposition temperature. The cell size of the porous SiOC ceramics depended on the size of polymer microbead added. The apparent cell sizes of $\mathrm{SiOC} 1$ and $\mathrm{SiOC} 2$, which were both prepared by the pyrolysis process, were $12.1 \pm 5.8 \mu \mathrm{m}$ and 26.8 $\pm 12.5 \mu \mathrm{m}$, respectively. The cell densities of the porous SiOC ceramics prepared by pyrolysis were $8.0 \times 10^{8} \mathrm{cells} / \mathrm{cm}^{3}$ for $\mathrm{SiOC} 1,2.6 \times 10^{7}$ cells $/ \mathrm{cm}^{3}$ for $\mathrm{SiOC} 2$, and $9.1 \times 10^{7}$ cells $/ \mathrm{cm}^{3}$
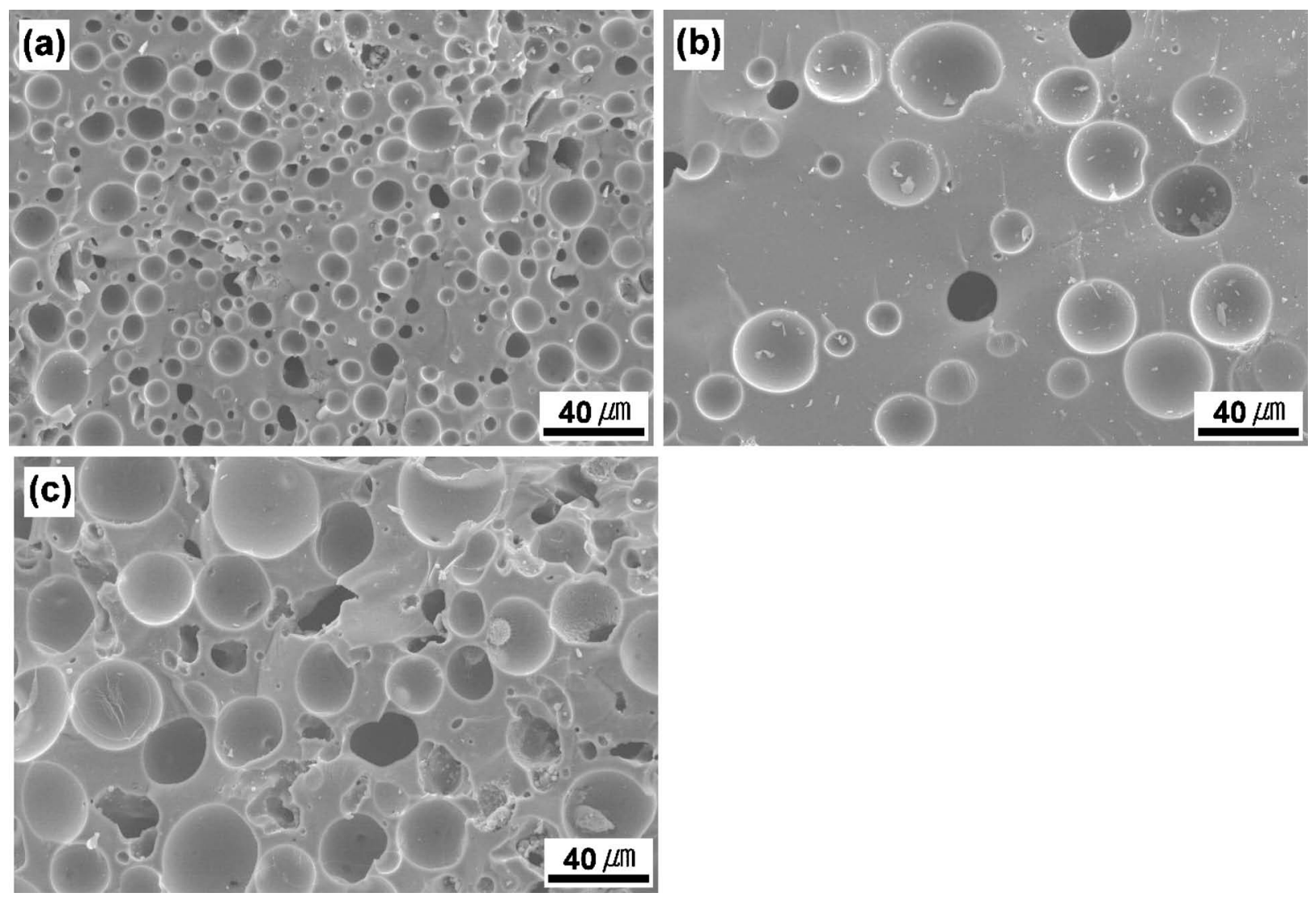

Fig. 1. Typical fracture surfaces of porous silicon oxycarbide ceramics prepared from extruded blends of polysiloxane and polymer microbeads. The extruded blends were pyrolyzed at $1200^{\circ} \mathrm{C}$ for $1 \mathrm{~h}$ with a heating rate of $2^{\circ} \mathrm{C} / \mathrm{min}$ in argon: (a) SiOC1, (b) SiOC2, and (c) SiOC3 (refer to Table 1). Note closed-cells in the porous ceramics. 
for SiOC3 (Fig. 2). It was observed that the use of a smaller microbead resulted in a porous ceramic with a higher cell density when the same content of microbead was added. Furthermore, the addition of a higher amount of microbeads resulted in ceramics with a greater cell density when we added

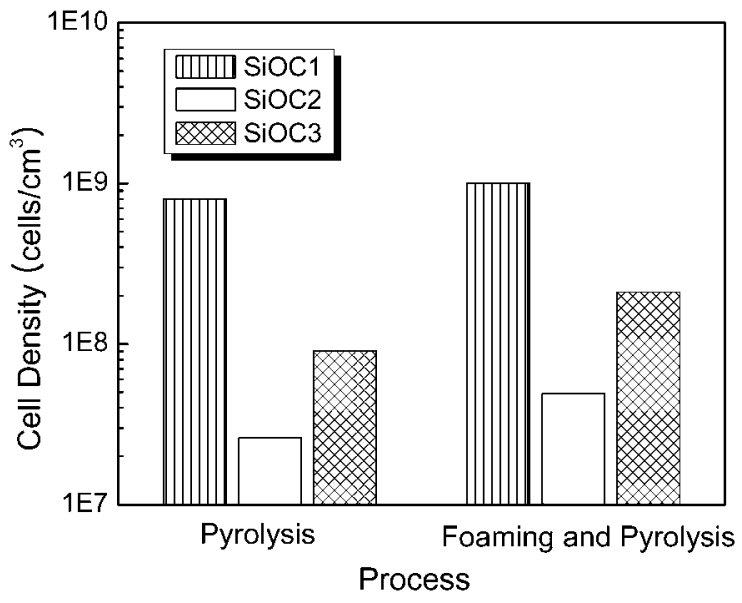

Fig. 2. Cell density of porous SiOC ceramics pyrolyzed at $1200^{\circ} \mathrm{C}$ for $1 \mathrm{~h}$ at a heating rate of $2^{\circ} \mathrm{C} / \mathrm{min}$ in argon. microbeads of the same size. The porosities of porous $\mathrm{SiOC}$ ceramics prepared by the pyrolysis process were $\sim 40 \%$ for $\mathrm{SiOC} 1, \sim 27 \%$ for $\mathrm{SiOC} 2$, and $\sim 58 \%$ for SiOC3 (Fig. 3 ). The use of a higher amount of microbeads led to a higher porosity when the same size of microbead was added. The
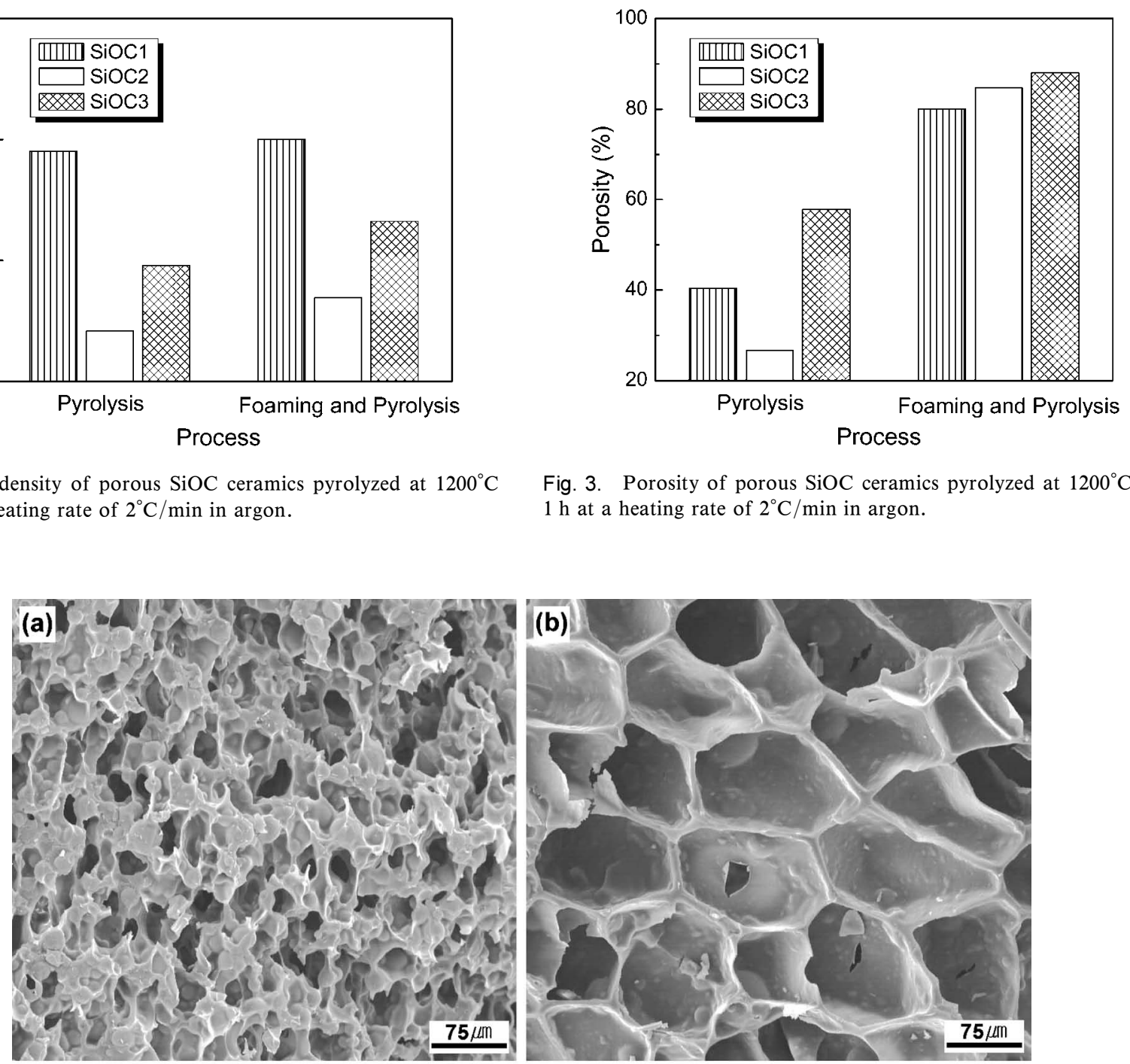

Fig. 3. Porosity of porous SiOC ceramics pyrolyzed at $1200^{\circ} \mathrm{C}$ for $1 \mathrm{~h}$ at a heating rate of $2^{\circ} \mathrm{C} / \mathrm{min}$ in argon.
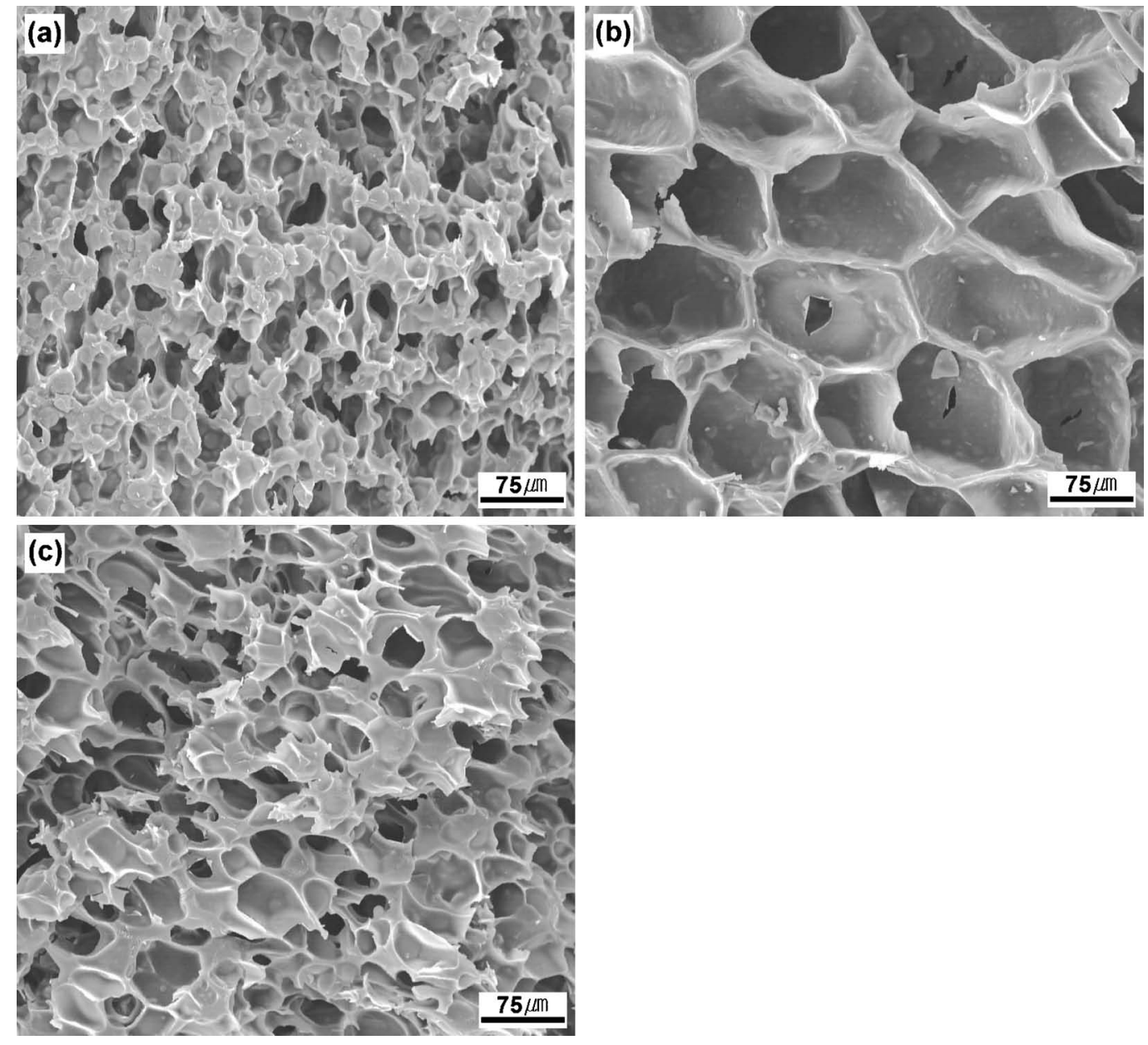

Fig. 4. Typical fracture surfaces of foamed polysiloxane and microbead blends. The extruded blends were saturated at room temperature for $24 \mathrm{~h}$ with gaseous $\mathrm{CO}_{2}$ under a pressure of $5.5 \mathrm{MPa}$ and foamed at room temperature at a pressure drop rate of $3.9 \mathrm{MPa} / \mathrm{s}$ : (a) SiOC1, (b) SiOC2, and (c) SiOC3 (refer to Table 1). 

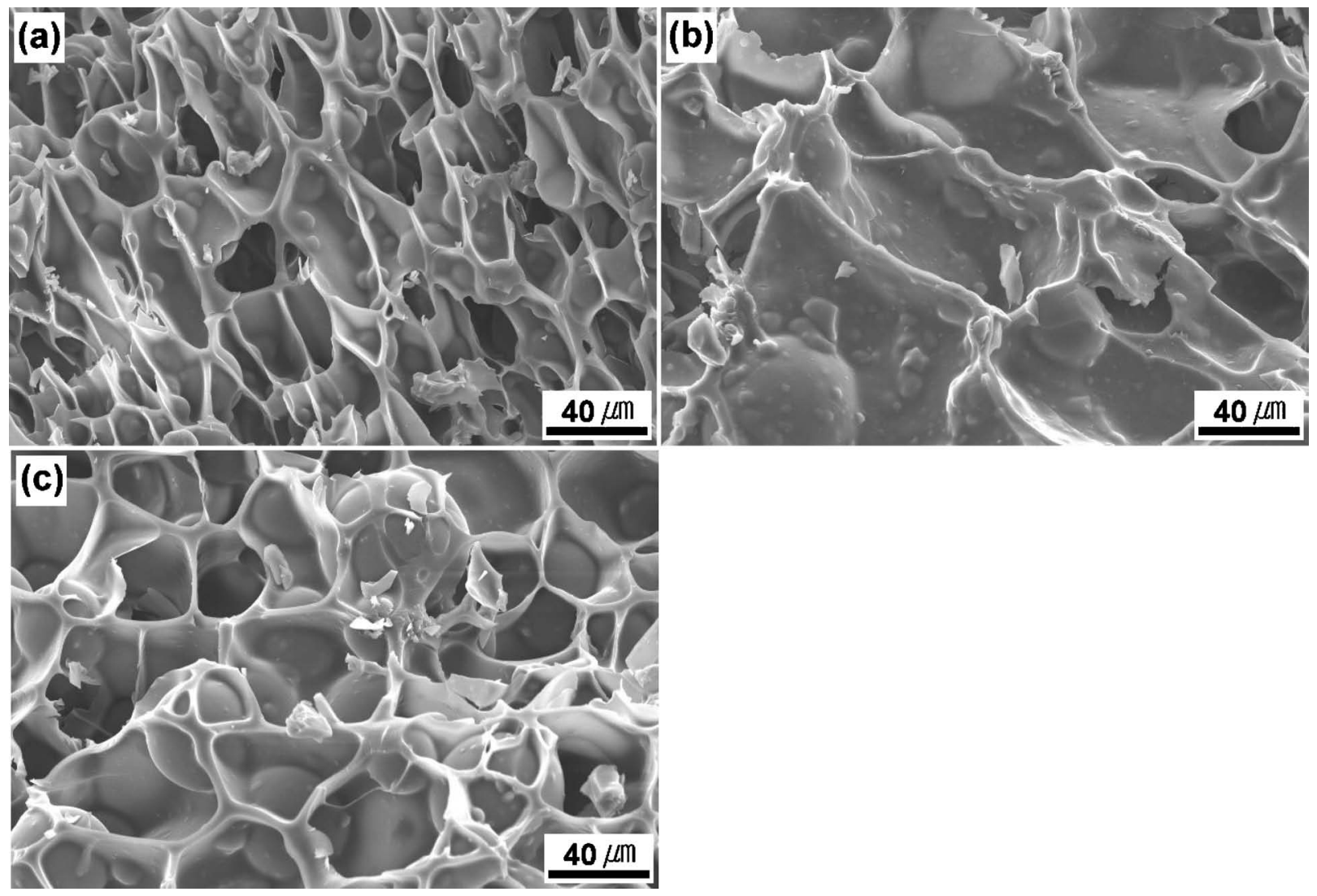

Fig. 5. Fracture surfaces of foamed polysiloxane and microbead blends at a higher magnification for corresponding specimens in Fig. 4. Note microbeads in the inside of cells.

present results suggest that by controlling both the microbead size and content, one can regulate, to a certain degree, the cell size, cell density, and porosity of porous SiOC ceramics.

Figure 4 shows the typical microstructures of the foamed specimens. The extruded blends were saturated with gaseous $\mathrm{CO}_{2}$. When depressurized, cellular structures were formed due to the plasticizing effect of gaseous $\mathrm{CO}_{2}$ dissolved in polysiloxane. ${ }^{12)}$ It was difficult to accurately measure the expansion ratio of specimens because of the plasticizing effect of gaseous $\mathrm{CO}_{2}$ on polysiloxane. The expansion ratio was roughly 1.5-2.5 times on the present compositions. The cell densities of foamed polysiloxane-microbead blends were $1.3 \times 10^{8}$ cells/ $\mathrm{cm}^{3}$ for $\mathrm{SiOC} 1,1.0 \times 10^{7}$ cells $/ \mathrm{cm}^{3}$ for $\mathrm{SiOC} 2$, and $8.1 \times 10^{7}$ cells $/ \mathrm{cm}^{3}$ for SiOC3. The use of a smaller microbead resulted in a higher cell density when foaming was performed at a constant concentration of microbead. Furthermore, adding a greater amount of microbeads resulted in ceramics with a higher cell density when we added microbeads of the same size. Higher magnification-microstructures of the foamed specimens (see Fig. 5) show microbeads in cells, indicating that the microbead acts as a nucleating site for the cells during foaming. Thus, we surmised that the use of a smaller microbead led to a higher population density of nucleation sites per unit volume, resulting in an overall higher cell density.

After subjecting the foamed specimens to cross-linking and pyrolysis, the cellular structures were unchanged, as shown in Fig. 6. The cross-linking of the foamed specimens was achieved by doping a condensation catalyst and subsequently heating them to $200^{\circ} \mathrm{C}$. The cross-linking process ensured that the foamed specimens would maintain their foamed structures during pyrolysis; in consequence, porous SiOC ceramics were finally fabricated. By combining the foaming and the pyrolysis processes, a homogeneous, open-cell SiOC ceramic was produced at a temperature as low as $1200^{\circ} \mathrm{C}$.

A morphological examination of the cells showed that they were mostly open cells. The cell densities of the foamed and pyrolyzed specimens $\left(4.9 \times 10^{7} \sim 1.0 \times 10^{9}\right.$ cells $/ \mathrm{cm}^{3}$, see Fig. 2) were higher than those of the foamed specimens $(1.0$ $\times 10^{7} \sim 1.3 \times 10^{8}$ cells $/ \mathrm{cm}^{3}$ ) because of both the burn-out of the polymer microbead and the shrinkage that accompanied the pyrolysis. ${ }^{14)}$ In this process, the same tendency characteristic of the pyrolysis process was also observed with respect to the cell density. In other words, the use of a smaller microbead led to a higher cell density when the same content of microbead was added, and the addition of a greater number of microbeads led to a higher cell density when the same size of microbead was added. The porosities of porous SiOC ceramics prepared by a combination of foaming and pyrolysis were $\sim 80 \%$ for $\mathrm{SiOC} 1, \sim 85 \%$ for $\mathrm{SiOC} 2$, and $\sim 88 \%$ for SiOC3 (Fig. 3). The porosity increased as the microbead content and size were similarly increased. Importantly, the porosity of $\mathrm{SiOC} 2$ was lower than that of $\mathrm{SiOC} 1$ in the pyrolysis process; however, the opposite result was obtained in the combined foaming-pyrolysis process. The cells in the pyrolysis process were formed when the microbead was burned out. In contrast, the cells that were produced by the foaming-pyrolysis process were yielded by foaming with gaseous $\mathrm{CO}_{2}$ and burning out the microbead content.

The cell size of SiOC2 in the foamed specimen was larger than that of SiOC1. The apparent cell sizes of foamed SiOC1 and $\mathrm{SiOC} 2$ were $38.7 \pm 12.2 \mu \mathrm{m}$ and $90.5 \pm 17.4 \mu \mathrm{m}$, respec- 

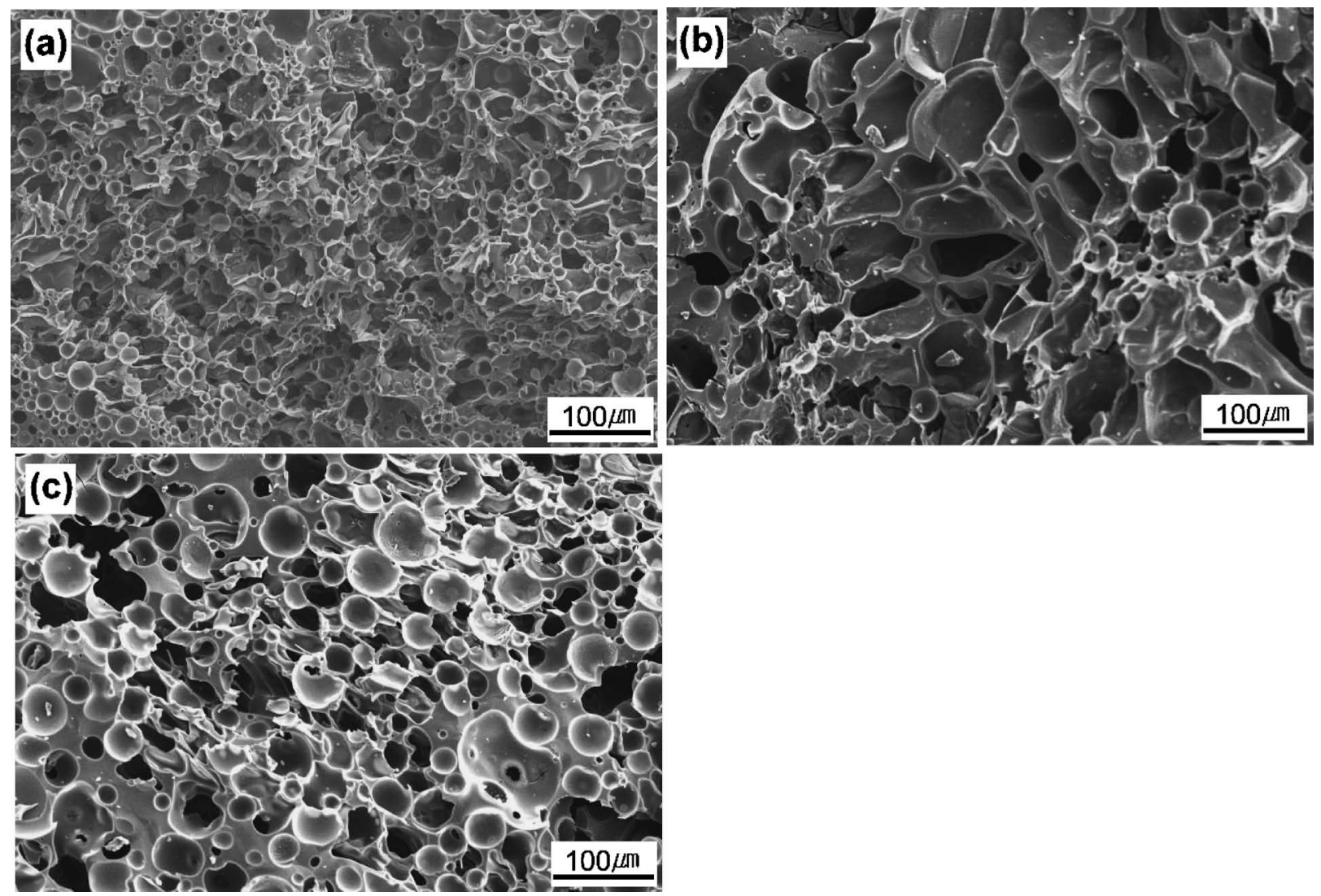

Fig. 6. Typical fracture surfaces of porous SiOC ceramics that were prepared from the foamed polysiloxane and microbead blends shown in Fig. 4. The foamed blends were pyrolyzed at $1200^{\circ} \mathrm{C}$ for $1 \mathrm{~h}$ in argon: (a) SiOC1, (b) SiOC2, and (c) SiOC3 (Refer to Table 1).

tively. The difference in cell size was attributed to the difference in the population density of nucleation sites. A larger number of microbeads in SiOC1 led to a greater degree of cell nucleation, but they were not coalescenced, resulting in smaller cells. A smaller number of microbeads in SiOC2 resulted in a smaller degree of cell nucleation; larger cells were in turn produced. Thus, the porosity of SiOC2, which was higher than that of SiOC1 in the foaming-pyrolysis process, was attributed to the formation of larger cells in SiOC2, as well as to the addition of a smaller amount of microbeads. Thus, the size of microbeads in the foaming-pyrolysis process was a key factor in controlling the cell density and porosity in the final porous ceramics.

From the difference in porosities between the pyrolyzed and the foamed and pyrolyzed specimens, the contribution from expansion (i.e., foaming using $\mathrm{CO}_{2}$ ) to the total porosity was estimated for each specimen. The contribution from the expansion to the total porosity was $\sim 40 \%$ for $\mathrm{SiOC} 1, \sim 58 \%$ for $\mathrm{SiOC} 2$, and $\sim 30 \%$ for $\mathrm{SiOC} 3$. The addition of a smaller number of microbeads led to a higher contribution of the expansion to the porosity when the same size of microbead was added. This result is consistent with the observed larger cells in SiOC2 (Fig. 4) and can be explained by the above discussion on cell size.

\section{Conclusions}

Homogeneous closed-cell and open-cell SiOC ceramics were fabricated at a temperature as low as $1200^{\circ} \mathrm{C}$ using two different processes: the first entailed pyrolyzing the extruded polysiloxane-microbead blends, while the second involved foaming the extruded blends and subsequently subjecting them to pyrolysis. The porosity was controlled such that it ranged between $27 \%$ to $88 \%$, and the cell density was regulated such that it spanned from $2.6 \times 10^{7}$ cells $/ \mathrm{cm}^{3}$ to $1.0 \times 10^{9}$ cells $/ \mathrm{cm}^{3}$. The ability to dictate porosity and cell density was a function of controlling the size and amount of polymer microbead.

Acknowledgments One of authors (Y-W Kim) gratefully acknowledges helpful discussions with Professor Masaki Narisawa at Osaka Prefecture University. This work was supported by the Korea Research Foundation Grant (KRF-2006311-D00534), which is funded by the Korean Government (MOEHRD, Basic Research Promotion Fund).

\section{References}

1) Passalacqua, E., Freni, S. and Barone, F., Mater. Lett., Vol. 34, pp. 257-262 (1998).

2) Zhu, X., Jiang, D. and Tan, S., Mater. Sci. Eng. A, Vol. 323, pp. 232-238 (2002).

3) Colombo, P. and Bernardo, E., Comp. Sci. Tech., Vol. 63, pp. 2353-2359 (2003).

4) Kitaoka, S., Matsushima, Y., Chen, C. and Awaji, H., J. Am. Ceram. Soc., Vol. 87, pp. 906-913 (2004).

5) Fukushima, M., Zhou, Y., Miyazaki, H., Yoshizawa, Y., Hirao, K., Iwamoto, Y., Yamazaki, S. and Nagano, T., J. Am. Ceram. Soc., Vol. 89, pp. 1523-1529 (2006).

6) Kim, Y.-W., Jin, Y. J., Chun, Y. S., Song, I. H. and Kim, H. D., Scripta Mater., Vol. 53, pp. 921-925 (2005).

7) Studart, A. R., Gonzenbach, U. T., Tervoort, E. and Gauckler, L. J., J. Am. Ceram. Soc., Vol. 89, pp. 1771-1789 (2006).

8) Fitzgerald, T. J., Michaud, V. J. and Mortensen, A., J. Mater. Sci., Vol. 30, pp. 1037-1045 (1995).

9) Colombo, P. and Modesti, P. M., J. Am. Ceram. Soc., Vol. 82, pp. 573-578 (1999). 
10) Zeschky, J., Goetz-Neunhoeffer, F., Neubauer, J., Jason Lo, S. H., Kummer, B., Scheffler, M. and Greil, P., Comp. Sci. Tech., Vol. 63, pp. 2361-2370 (2003).

11) Colombo, P., Bernardo, E. and Biasetto, L., J. Am. Ceram. Soc., Vol. 87, pp. 152-154 (2004).

12) Kim, Y.-W. and Park, C. B., Comp. Sci. Tech., Vol. 63, pp. 2371-2377 (2003).

13) Kim, Y.-W., Kim, S. H., Wang, C. and Park, C. B., J. Am. Ceram. Soc., Vol. 86, pp. 2231-2233 (2003).
14) Kim, Y.-W., Kim, S. H., Kim, H. D. and Park, C. B., J. Mater. Sci., Vol. 39, pp. 5647-5652 (2004).

15) Kim, Y.-W., Kim, S. H., Park, C. B. and Kim, H. D., Key Eng. Mater., Vol. 317-318, pp. 899-904 (2006).

16) Wang, C., Wang, J., Park, C.B. and Kim, Y.-W., J. Ceram. Soc. Japan, Vol. 114, pp. 000-000 (2006).

17) Kim, Y.-W., Kim, S. H., Song, I. H., Kim, H. D. and Park, C. B., J. Am. Ceram. Soc., Vol. 88, pp. 2949-2951 (2005). 